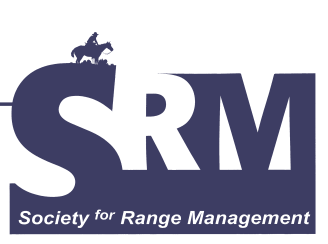

\section{Masonic Range Science Scholarship}

\section{By Jennifer Pluhar}

"A group of SRM members who are Masons want to give a scholarship to a student studying range science," said Lorenz Brademeier after he approached me in the Trade Show at the 1989 SRM Annual Meeting in Billings, Montana. Before I could react, he handed me a check for $\$ 5,000$ and said, "We plan to raise more for the scholarship fund." As Chair of the Student Affairs (now Student Activities) Committee, nothing had prepared me for his generous offering. I certainly wasn't going to dissuade his interest and quickly said something about how happy the committee would be to hear this news and that we would begin working on a means of awarding the scholarship immediately.

Initial guidelines provided by $\mathrm{Mr}$ Brademeier, as developed by the original donors, included plans to offer the award to "a high school graduate with an interest in range management and a desire to attend college." Further, the donors wanted to focus on a student who had demonstrated "leadership qualities and high moral standards" and had financial need. With these basic guidelines, the Student Affairs Committee worked with Pete Jackson, then SRM Executive Vice President, to hammer out criteria and a method for making our first Masonic Range Science Scholarship award at the 1990 Annual Meeting. Although the committee had one scholarship in its history, the K.S. "Boots" Adams Scholarship, we struggled to develop a firm foundation upon which to build the Masonic Range Science Scholarship. The Boots Adams Scholarship was more of an internship for a range student, and involved spending the summer on a ranch getting some "hands-on" experience.

We had a dual purpose: to develop a means to award the Masonic Range Science Scholarship and a means to raise donations to the corpus of the scholarship fund. The guidance of several wise Masons led to the scholarship being advertised through the National Association of Conservation Districts and the Soil and Water Conservation Society, as well as through SRM. An applicant could be "sponsored" by a member of any of the 3 organizations.

We finally settled upon offering the scholarship to a high school senior, developed a basic application form, and asked applicants to submit 3 reference letters and a letter stating why they wanted to study range science. Sections were encouraged to urge their best and brightest youths to apply.

I cannot recall how many applications we received that first year. I do, however, vividly recall awarding the tidy sum of $\$ 346$ to the first Masonic Range Science Scholar, Shelly Susanne Smith of El Paso, Texas. Shelly planned to study range science at New Mexico State University. I had the pleasure of awarding this scholarship to Shelly in front of her class at NMSU. She was thrilled with the award.

Our fund gradually grew. In 1993, we were able to award a larger sum of money. We realized it was necessary to develop a more structured application and judging process. Each section of today's scholarship applications is scored. As many as 15 judges review the applications and score each applicant, following the same guidelines. After the high and low scores are dropped for each applicant, the scores are tallied and a recipient selected.

The Masonic Range Science Scholarship has been in the $\$ 6,000-\$ 8,000$ range annually for several years now. Significant growth from $\$ 346$ only 15 years ago! The committee and donors have toyed with the idea of making more than one award, but have decided to stick with one significant award at this time. Masonic Range Science Scholars receive their funds through their colleges, spread out over 6 or 8 semesters, the remainder of their college careers. They must maintain a 3.0 grade point average and continue to major in range science or a closely related discipline. As of 2005 , over $\$ 56,000$ has been awarded.

Robin Morris, Masonic Range Science Scholar (2003), a junior at Texas Tech majoring in range science, has enthusiastically tackled her chosen major, participating on the plant identification team and in other activities available to students at the Annual Meetings. Robin lists the Masonic Range Science Scholarship as one of her proudest accomplishments. Certainly the Masonic Range Science Scholarship is recognized as a significant award for a student studying range science or a closely related field. It is the dream of the donors and the committee to have many more students wear the prestigious label of "SRM Masonic Range Science Scholar" in the years to come.

Author is Cochair of the SRM Student Activities Committee's Masonic Range Science Scholarship Subcommittee.

Editor's Note: The 2005 Masonic Range Science Scholarship winner is Shiloh Long. See photo in Youth Awards, $p 55$. 